\title{
Engineered Pichia pastoris for enhanced production of S-adenosylmethionine
}

\author{
Venu Kamarthapu1, Srinivas Ragampeta ${ }^{2}$, Khareedu Venkateswara Rao ${ }^{1}$ and Vudem Dashavantha Reddy ${ }^{1 *}$
}

\begin{abstract}
A genetically engineered strain of Pichia pastoris expressing S-adenosylmethionine synthetase gene from Saccharomyces cerevisiae under the control of AOX 1 promoter was developed. Induction of recombinant strain with 1\% methanol resulted in the expression of SAM2 protein of $\sim 42 \mathrm{kDa}$, whereas control GS115 showed no such band. Further, the recombinant strain showed 17-fold higher enzyme activity over control. Shake flask cultivation of engineered P. pastoris in BMGY medium supplemented with $1 \% \mathrm{~L}$-methionine yielded $28 \mathrm{~g} / \mathrm{L}$ wet cell weight and $0.6 \mathrm{~g} / \mathrm{L} \mathrm{S}$-adenosylmethionine, whereas control (transformants with vector alone) with similar wet cell weight under identical conditions accumulated $0.018 \mathrm{~g} / \mathrm{L}$. The clone cultured in the bioreactor containing enriched methionine medium showed increased WCW $(117 \mathrm{~g} / \mathrm{L})$ as compared to shake flask cultures and yielded $2.4 \mathrm{~g} / \mathrm{L} \mathrm{S}$-adenosylmethionine. In spite of expression of SAM 2 gene up to $90 \mathrm{~h}$, S-adenosylmethionine accumulation tended to plateau after $72 \mathrm{~h}$, presumably because of the limited ATP available in the cells at stationery phase. The recombinant $P$ pastoris seems promising as potential source for industrial production of S-adenosylmethionine.
\end{abstract}

Keywords: S-adenosylmethionine synthetase; Pichia pastoris; Heterologous host; Bioreactor

\section{Introduction}

S-adenosylmethionine (SAM) is a metabolite of the methionine metabolism. In diverse living organisms, it is known to mediate three important metabolic pathways, viz., transmethylation, trans-sulphuration, and aminopropylation (Chiang et al. 1996; Bottiglieri 2002; Fontecave et al. 2004; Roje 2006) SAM is also involved in various other reactions that occur through radical-based catalysis (Grillo and Colombatto 2007). It is known to act as a key physiological compound essential for optimal hepatic function, proper functioning of joints, as well as gastric mucosa protection ( $\mathrm{Lu}$ 2000; Lu and Mato 2008). As such, it is used extensively in mitigating depression, liver disease and osteoarthritis (Castillo et al. 2005; Papakostas et al. 2003; Mischoulon et al. 2012; Ringdahl and Pandit 2011; Papakostas et al. 2012; Harmand et al. 1987).

However, use of SAM for therapeutic applications is extremely limited owing to its expensive nature. Hence, it is imperative to develop an efficient method for production of

\footnotetext{
* Correspondence: vdreddycpmb@yahoo.com

${ }^{1}$ Centre for Plant Molecular Biology, Osmania University, Hyderabad 500 007, India

Full list of author information is available at the end of the article
}

SAM. Several attempts have been made to isolate genetic strains accumulating higher concentration of SAM. Yeast strains have been isolated that could accumulate increased concentration of SAM in comparison with other microorganisms (Shiozaki et al. 1984). An efficient positive selection method has been optimized for isolation of SAM accumulating yeast strains with significant increases in SAM content on a dry cell weight basis. Nonetheless, the volumetric yield of SAM is low as most of the strains belonged to Saccharomyces cerevisiae and were hardly able to attain high cell density using minimal media (Shobayashi et al. 2006).

The methylotrophic yeast, Pichia pastoris, was found to serve as an outstanding host for enhanced production of different proteins (Garg et al. 2012; Lee et al. 2013; Clare et al. 1991; Cregg et al. 1993). P. pastoris demonstrated ample potential for high-level expression, efficient secretion and growth rate with very high cell densities. The success of $P$. pastoris system was attributed to its strong, tightly-regulated alcohol oxidase (AOX1) promoter (Duff and Murray 1988; Cregg et al. 1989). This promoter can be strongly induced by methanol which also can serves as the main carbon source (Ellis et al. 1985), 
and repressed by most other carbon sources (Tschopp et al. 1987). Accumulation of methanol leads to cytotoxic effects (Guarna et al. 1997) and induction of the promoter is optimal when the methanol level is kept within growth limiting rates. Another unique feature of this system is that a high cell density can be achieved using the cost-effective, minimal salt medium. Thus far, more than 500 genes of viruses, prokaryotic and eukaryotic microorganisms, plants and humans have been expressed in the $P$. pastoris system (Sreekrishna et al. 1988; Scorer et al. 1994; Cereghino and Cregg 2000; Macauley-Patrick et al. 2005).

Among different SAM synthetase isozymes identified in various microorganisms and animal tissues, SAM synthetase of S. cerevisiae exhibited some rare advantages. Expression of $S$. cerevisiae SAM2 gene was induced by the presence of excess methionine in the growth medium, while expression of $S A M 1$ gene was repressed, thereby obviating the problem of product inhibition observed with other SAM synthetases (Chiang and Cantoni 1977; Cherest and Surdin-Kerjan 1981; Thomas et al. 1988).

Attempts have been made to improve the production of SAM in P. pastoris using various methods, viz., transformation with SAM2 gene of S. cerevisia (Li et al. 2002); expression of SAM2 under the control of a constitutive promoter (Yu et al. 2003); co-production of SAM with glutathione by fed-batch fermentation (Lin et al. 2004); and employment of altered feeding strategy in a bioreactor (Hu et al. 2009). $S A M 2$ gene was expressed and cystathione- $\beta$-synthase gene was knocked out from $P$. pastoris for production of SAM (He et al. 2006; Yu and Shen 2012). Enhanced accumulation of SAM was achieved by manipulating the culture conditions like increased oxygen levels and nitrogen source (Chen et al. 2007; Zhang et al. 2008a; Zhang et al. 2008b; Chu et al. 2013). Earlier studies reported elevated intracellular production of SAM using recombinant $P$. pastoris; however, these reports did not confirm the expression of the enzyme by SDS-PAGE analyses, and molecular characterization of the accumulated SAM using MS/MS method.

In the present study, we have cloned SAM2 gene from $S$. cerevisiae, introduced into the genome of $P$. pastoris, and optimized the conditions for cultivation of the engineered P. pastoris in the methionine-enriched medium for enhanced accumulation of SAM in shake flask. Furthermore, the recombinant $P$. pastoris has been cultivated in a $14 \mathrm{~L}$ bioreactor to increase the wet cell weight and SAM accumulation. The accumulated SAM has been identified, quantified and characterized by HPLC and LC-MS/MS analyses.

\section{Materials and methods}

\section{Amplification and cloning of S. cerevisiae SAM} synthetase gene

S. cerevisiae strain INVSc1 (invitrogen) was grown in the YPD medium (1\% Peptone, 2\% Yeast extract, 2\% dextrose) overnight at $30^{\circ} \mathrm{C}$ at $220 \mathrm{rpm}$. Gnomic DNA was isolated as per the protocol of Sambrook and Russel (2001). Amplification of SAM synthetase coding sequence was carried out employing the primers, 5'GCGCGGATCCACCATGG CCAAGAGCAAAACTTTC 3' and 5'GCGCGAATTC TTAAAATTCCAATTTCTTTGG 3'. Amplified SAM sequence was digested with $B a m \mathrm{H}$ I and $E c o$ R I and cloned in to pPIC3.5 K vector. Recombinants were identified by restriction analysis of plasmid DNA with BamH I- EcoR I, Sac I, Nco I and Nde I and were confirmed by sequencing of both the strands.

\section{Transformation of Pichia pastoris by electroporation method} A single colony of $P$. pastoris (GS115) was inoculated into $5.0 \mathrm{ml}$ of YPD medium in a $50 \mathrm{ml}$ conical flask and grown at $30^{\circ} \mathrm{C}, 280 \mathrm{rpm}$ for overnight. Next day, $500 \mathrm{ml}$ of YPD medium was inoculated with $0.5 \mathrm{ml}$ of overnight culture and grown at $30^{\circ} \mathrm{C}, 280 \mathrm{rpm}$ until the cell density reached $\mathrm{OD}_{600}=1.5$. The culture was centrifuged at 5000 $\mathrm{xg}$ for $5 \mathrm{~min}$ at $4^{\circ} \mathrm{C}$, and the pellet was re-suspended in $500 \mathrm{ml}$ of ice-cold sterile water. The cells were centrifuged again, and then re-suspended the pellet in $250 \mathrm{ml}$ of ice-cold sterile water. The centrifugation was repeated as above and re-suspended the pellet in $20 \mathrm{ml}$ ice-cold $1.0 \mathrm{M}$ sorbitol. These cells were later centrifuged at $5000 \mathrm{xg}$ for $5 \mathrm{~min}$ at $4^{\circ} \mathrm{C}$, and the pellet was re-suspended in $1.0 \mathrm{ml}$ of ice-cold 1.0 M sorbitol. From the suspension, $80 \mu \mathrm{l}$ of cells were mixed with $20 \mu \mathrm{g}$ of Sac I linearized pPIC3.5 K-SAM2/20 $\mu \mathrm{g}$ pPIC3.5 K DNA (vector alone) and the same were transferred into ice-cold $4 \mathrm{~mm}$ electroporation cuvette, and the cuvettes with cells were incubated on ice for $5 \mathrm{~min}$. The various parameters of the pulse generator (Electro Cell Manipulator ECM 600 BTX Electronic Genetics, San Diego, CA) were setup as follows: high-voltage mode, resistance 129 Ohms, charging voltage of $1.5 \mathrm{kV}$, estimated field strength of $7.5 \mathrm{kV} / \mathrm{cm}$ and pulse length of $5 \mathrm{msec}$. Cuvette was placed in the electroporation chamber, connected to the pulse generator and subjected to two pulses; followed by immediate addition of $1.0 \mathrm{ml}$ of ice-cold 1.0 M sorbitol to the cuvette. The cuvette contents were transferred to the sterile microcentrifuge tube; from this an aliquot of $500 \mu \mathrm{l}$ was plated on RDB medium (1.0 M sorbitol, $2 \%$ dextrose, $1.34 \%$ of yeast nitrogen base with ammonium sulphate, $0.4 \mathrm{mg} / \mathrm{L}$ biotin, $2 \%$ bactoagar and $0.005 \%$ of each L-glutamic acid, Lmethioninie, L-lysine, L-leucine, and L-isoleucine) lacking Histidine. The plates were incubated for 3 to 5 days at $29^{\circ} \mathrm{C}$ until $\mathrm{His}^{+}$recombinant colonies were developed.

\section{Screening of recombinant $\left(\mathrm{His}^{+}\right)$colonies with multiple inserts using antibiotic G418}

Two hundred microlitres of YPD medium was placed in each well of the microtiter plate (96 wells) under sterile conditions. Each well was inoculated with a single $\mathrm{His}^{+}$ 
transformant using a sterile toothpick and stirred to resuspend the cells. The microtiter plates were covered with sterile aluminum foil and incubated at $30^{\circ} \mathrm{C}$ for 2 days. Later, sterile microtiter plates were used and added with $190 \mu \mathrm{l}$ of YPD medium in each well, and inoculated with $10 \mu \mathrm{l}$ of the culture from the first set of microtiter plates. Second set of plates were marked and oriented to keep track of the wells. The plates were covered and incubated at $30^{\circ} \mathrm{C}$ for overnight. Next day, a third set of microtiter plates were sub-cultured as described above. Again the plates were incubated at $30^{\circ} \mathrm{C}$ for overnight. From the third set of plates, $10 \mu \mathrm{l}$ of culture from each well was spotted on YPD plates containing 0, 0.25, 0.5, 1.0 and $2.0 \mathrm{mg} / \mathrm{ml}$ of G418. Plates were marked properly to track all the clones at different concentrations of G418. Plates were incubated at $29^{\circ} \mathrm{C}$, and checked after $2^{\text {nd }}, 3^{\text {rd }}, 4^{\text {th }}$ and $5^{\text {th }}$ day for G418 resistant clones.

\section{Colony PCR screening for presence of SAM2 gene in recombinant clones}

From $2 \mathrm{mg} / \mathrm{ml}$ G418 plate, a single colony was picked up and re-suspended in the $10 \mu \mathrm{l}$ of sterile water in the micro centrifuge tube. To this, $5.0 \mu \mathrm{l}$ of $10 \mathrm{U} / \mu \mathrm{l}$ solution of Zymolase was added and incubated at $30^{\circ} \mathrm{C}$ for $15 \mathrm{~min}$. The tubes were then immersed in the liquid nitrogen for $2 \mathrm{~min}$. From the resulting lysate, $5.0 \mu \mathrm{l}$ was taken and the polymerase chain reaction was set up by adding 50 picomoles each of 5' AOX and 3' AOX primers. Introduced SAM2 gene was confirmed by the PCR employing gene specific primers. The clone has been designated as GS115-SAM2. After confirming clones, glycerol stocks were prepared and stored at $-70^{\circ} \mathrm{C}$.

\section{Culturing of recombinant $P$ pastoris (GS115-SAM2) in shake flask}

A single colony of GS115-SAM2/control GS115 transformed with vector alone, grown on YPD agar plate, was inoculated in $5.0 \mathrm{ml}$ of YPD medium and grown at $30^{\circ} \mathrm{C}, 280 \mathrm{rpm}$ for overnight, and was used as inoculum. All the shake flask experiments were carried out in $250 \mathrm{ml}$ conical flasks ( $25 \mathrm{ml}$ working volume). One percent of inoculum $(\mathrm{v} / \mathrm{v})$ was transferred into BMGY medium consisting of $1 \%$ yeast extract, $2 \%$ peptone, $1.34 \%$ of Yeast nitrogen base with ammonium sulphate and without amino acids, $4 \%$ of glycerol, $100 \mathrm{mM}$ potassium phosphate buffer ( $\mathrm{pH}$ 6.0) and $0.4 \mathrm{mg} / \mathrm{L}$ biotin with $1 \% \mathrm{~L}$-methionine. Culture was grown at $30^{\circ} \mathrm{C}, 280 \mathrm{rpm}$ until culture reached $\mathrm{OD}_{600}=3.0$. Methanol $(1 \% \mathrm{v} / \mathrm{v})$ was added after every $24 \mathrm{~h}$ to the culture and induction was continued for 4 days. Two milliliters of culture was withdrawn from each flask per every $24 \mathrm{~h}$ and centrifuged at $5000 \mathrm{x} \mathrm{g}$ for $3 \mathrm{~min}$. The pellet was stored at $-70^{\circ} \mathrm{C}$ until processing. These samples were used to analyze expression of heterologous SAM synthetase and accumulation of SAM to determine the optimal harvest time and selection of potential recombinant $P$. pastoris with maximum SAM accumulation. The cultures were centrifuged at $5000 \mathrm{x} \mathrm{g}$ for $5 \mathrm{~min}$, and the pellet was stored at $-70^{\circ} \mathrm{C}$.

\section{Fermentation of recombinant $P$. pastoris in bioreactor}

Fermentation was carried out in a $14 \mathrm{~L}$ bench top fermentor Bioflo 2000 (New Brunswick Scientific, Edison, NJ, USA). Seed culture of recombinant $P$. pastoris for fermentation was initiated from the fresh glycerol stock and inoculated into $250 \mathrm{ml}$ conical flask containing YPD medium (50 ml working volume) and grown for $24 \mathrm{~h}$. Four percent inoculum was used for inoculation of a $14 \mathrm{~L}$ fermentor containing 6.0 L of BMGY medium containing $1 \% \mathrm{~L}$-methionine. The aeration rate was initially maintained at $0.5 \mathrm{~min}^{-1} \mathrm{VVM}$ and then increased to $1.0 \mathrm{~min}^{-1} \mathrm{VVM}$ when required. Dissolved oxygen was kept above $20 \%$ by controlling the agitation between 400 and $600 \mathrm{rpm}$. The $\mathrm{pH}$ of the medium was controlled at 5.8 by adding ammonia solution. Temperature was maintained at $29^{\circ} \mathrm{C}$. Foaming was controlled by addition of $1.0 \mathrm{ml}$ of antifoam agent from Sigma Aldrich. Cells were grown until glycerol was completely depleted $(28 \mathrm{~h})$. Then, methanol feed was initiated and maintained at $1 \%$ throughout the fermentation. Samples were collected after every $12 \mathrm{~h}$ for SAM synthetase expression, SAM accumulation and biomass assay. The samples were centrifuged at $5000 \mathrm{xg}$ for $5 \mathrm{~min}$ and the pellet was stored at $-70^{\circ} \mathrm{C}$ for SDS-PAGE analysis. At the end of the fermentation, culture was centrifuged at $5000 \mathrm{x} \mathrm{g}$ for $10 \mathrm{~min}$ and the pellet was stored at $-70^{\circ} \mathrm{C}$.

\section{HPLC analysis of SAM}

Cells were collected by centrifugation and washed with water. SAM was extracted from the cells with $1.5 \mathrm{M}$ perchloric acid for $1 \mathrm{~h}$. The supernatant was collected after centrifugation at $8000 \mathrm{xg}$ for $5 \mathrm{~min}$. A $20 \mu \mathrm{l}$ of the extracted sample was analyzed by HPLC (Shimadzu, Japan) using a Hypersail SCX column $(4.6 \mathrm{~mm} \times 250 \mathrm{~mm}, 5 \mu \mathrm{m})$. The mobile phase consists of $100 \mathrm{mM}$ ammonium formate ( $\mathrm{pH}$ adjusted to 4.0 with formic acid). SAM accumulation was monitored at $\lambda=254 \mathrm{~nm}$, and was identified and quantified using the standard SAM (Sigma, USA).

\section{SDS-PAGE analysis and determination of enzyme activity}

The cell pellets from $1 \mathrm{ml}$ culture were resuspended in $500 \mu \mathrm{l}$ of ice-cold breaking buffer $(50 \mathrm{mM}$ sodium phosphate, 1.0 mM PMSF, 1.0 mM EDTA, 5\% glycerol, $\mathrm{pH}$ 7.4). An equal volume of acid-washed glass beads (size, $0.5 \mathrm{~mm}$ ), vortexed for 30 seconds, then incubated on ice for 30 seconds, repeated this step for a total of 8 cycles. After centrifugation at $10000 \mathrm{xg}$ for $5 \mathrm{~min}$ at $4^{\circ} \mathrm{C}$, the supernatant was transferred to a microcentrifuge tube and used for the analysis. From the above supernatant $50 \mu \mathrm{l}$ was mixed with $50 \mu \mathrm{l} 2 \mathrm{X}$ gel loading dye. From this 
$10 \mu \mathrm{l}$ was loaded onto $12 \%$ SDS-PAGE and subjected to electrophoresis. The gel was stained with Coomassie blueR250 and destained using solution (30:10:60 of methanol, acetic acid and water) till the protein bands were apparent on a clear background. Enzyme activity was determined as per the protocol of Kamarthapu et al. (2008).

\section{LC-MS/MS analysis}

A high performance liquid chromatography (HPLC) system Agilent 1200 series (Agilent Technologies, USA) was interfaced to a Q-TOF mass spectrometer (Agilent Technologies, USA). Chromatographic separation was achieved using an Eclipse XDB-C18, 5.0 $\mu \mathrm{m}$ particle size analytical column $(4.6 \times 150 \mathrm{~mm})$ from Agilent, at a flow rate of $1.0 \mathrm{ml} / \mathrm{min}$ with isocratic mobile phase (100 mM ammonium formate, $\mathrm{pH}$ was adjusted to 4.0 with formic acid). The elution profile was monitored by absorbance at $254 \mathrm{~nm}$ using G1315D multiple wavelength UV/VIS detector. After LC, sample enters in to the Mass spectrometer (Agilent 6510 series Classic G6510A Q-TOF LC/MS, Agilent Technologies, USA). Electrospray ionization (ESI) mass spectra were obtained by setting electrospray interface in positive-ionization mode with the skimmer potential $65 \mathrm{~V}$, capillary exit $80 \mathrm{~V}$, and a source of temperature at $300^{\circ} \mathrm{C}$, to obtain maximum abundance of the standard sample in full scan spectra (100-1000 Da, 10 full scan/s). Nitrogen was used as a drying $(6.0 \mathrm{~L} / \mathrm{min})$ and nebulizing gas (30 psi). Total ion chromatogram and mass spectra were processed using Agilent Mass Hunter workstation Software.

\section{Results}

Nucleotide sequence analysis of recombinant plasmid confirmed the presence of SAM2 (GenBank accession number KF142161). The recombinant plasmid pPIC3.5 K-SAM2 linearized with Sac I was introduced into P. pastoris strain GS115 by electroporation method. Following electroporation cells were plated onto selection medium-lacking Histidine. Two hundred and fifty colonies were observed after 5 days of plating. Further, these clones were subjected to antibiotic selection on YPD medium containing varied concentrations $(0.25-2.0 \mathrm{mg} / \mathrm{ml})$ of G418. Out of 250 clones, 208 could exhibit growth on $0.25 \mathrm{mg} / \mathrm{ml} \mathrm{G418} \mathrm{selection} \mathrm{medium;} \mathrm{of} \mathrm{these} 208$ clones, 127 of them showed growth on $0.5 \mathrm{mg} / \mathrm{ml} \mathrm{G418}$. From these 127 clones, 56 clones exhibited growth on $1.0 \mathrm{mg} / \mathrm{ml} \mathrm{G418}$ containing medium, whereas only 15 clones were able to grow on $2.0 \mathrm{mg} / \mathrm{ml} \mathrm{G418} \mathrm{containing} \mathrm{medium.}$

$\mathrm{His}^{+}$transformants, selected on YPD plates containing

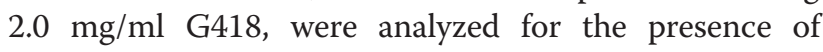
SAM2 gene using colony PCR. PCR analysis revealed the presence of a faint band of $\sim 2.2 \mathrm{~Kb}$ corresponding to the $A O X 1$ gene, and a $1.4 \mathrm{~Kb}$ amplification product composed of SAM2 gene and 220 bp sequence from the pPIC3.5 K vector (Figure 1a). The untransformed $P$. pastoris GS115 resulted in a bright band of $\sim 2.2 \mathrm{~Kb}$ corresponding to the $A O X 1$ gene (Figure 1a). PCR analysis using the $S A M 2$ gene specific primers resulted in $\sim 1.2 \mathrm{~Kb}$ amplification product corresponding to $S A M 2$ gene, while untransformed GS115 failed to show the band (Figure 1b).

\section{Expression of recombinant SAM synthetase and production of SAM in the shake flask cultures}

Induction of recombinant $P$. pastoris with $1 \%$ methanol at log phase of $\mathrm{OD}_{600}=3.0$ and $\mathrm{pH}$ of 6.0 , resulted in the expression of $S A M 2$ protein of $\sim 42 \mathrm{kDa}$, whereas control GS115 showed no such band (Figure 2). All the 15 clones, expressing SAM2 gene, exhibited enhanced accumulation of the SAM, when compared to the control GS115 transformed with the vector alone. One of the high expressing transformant was selected for further studies, which yielded wet cell weight $(28 \mathrm{~g} / \mathrm{L})$ and SAM $(0.6 \mathrm{~g} / \mathrm{L}$ or $0.195 \mathrm{~g} / \mathrm{g} \mathrm{DCW}$ ). Whereas, the control (transformant with vector alone), under the identical culture conditions with similar wet cell mass, produced $0.018 \mathrm{~g} / \mathrm{L}$ SAM (Figure 3) or $0.0054 \mathrm{~g} \mathrm{SAM} / \mathrm{g}$ DCW. Further, the clone expressing
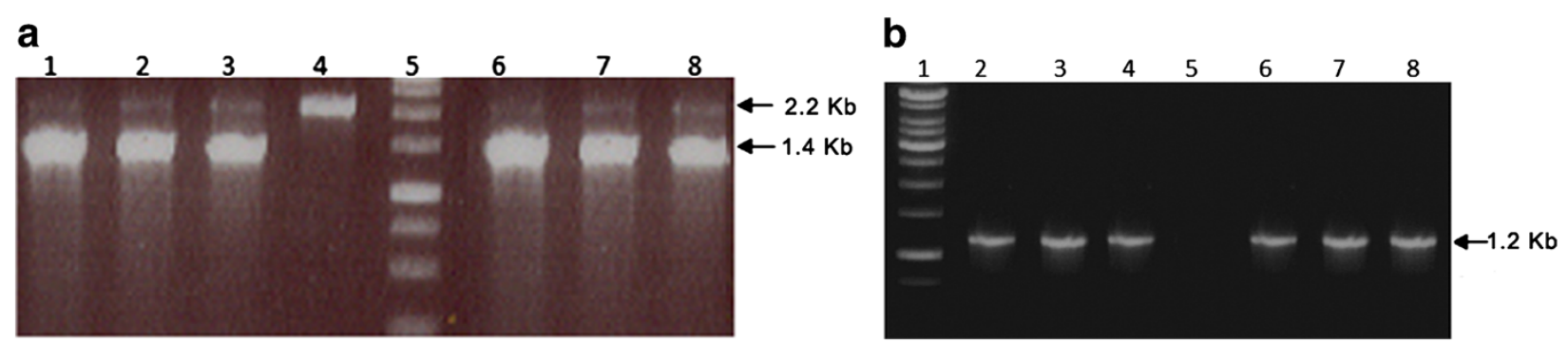

Figure 1 Confirmation of transformed clones of $P$. pastoris by colony PCR with AOX and gene specific primers. a: Amplification with AOX primers. Lanes 1, 2, 3, 6, 7 and 8: Clones exhibiting an amplified thick band of $1.4 \mathrm{~Kb}$ SAM2 gene and a faint band of $2.2 \mathrm{~Kb}$ AOX gene. Lane 4: Untransformed colony exhibiting amplified band of $2.2 \mathrm{~Kb}$ AOX gene. Lane 5: DNA Marker (1.0 Kb ladder) showing bands of $250 \mathrm{bp}, 500 \mathrm{bp}$, $750 \mathrm{bp}, 1.0 \mathrm{~Kb}, 1.5 \mathrm{~Kb}, 2.0 \mathrm{~Kb} \& 2.5 \mathrm{~Kb}$. b: Amplification with gene specific primers of SAM2 gene. Lane 1: DNA Marker (1.0 Kb ladder) showing bands of $750 \mathrm{bp}, 1 \mathrm{~Kb}, 1.5 \mathrm{~Kb}, 2.0 \mathrm{~Kb}, 2,5 \mathrm{~Kb}, 3.0 \mathrm{~Kb}, 3.5 \mathrm{~Kb}, 4.0 \mathrm{~Kb}, 5.0 \mathrm{~Kb}$ and $6.0 \mathrm{~Kb}$. Lanes 2, 3, 4, 6, 7 and 8: Clones exhibiting amplified band of $\sim 1.2 \mathrm{~Kb}$ corresponds to SAM2 gene. Lane 5: Untransformed GS115 strain showing no amplification. 
Figure 2 SDS-PAGE analysis showing expression of Saccharomyces SAM synthetase in P. pastoris. Lane 1: Control, GS115 transformed with vector alone showing no expression of SAM synthetase. Lane 2: Recombinant P. pastoris showing induced band of SAM synthetase $(\sim 42 \mathrm{kDa})$. Lane 3: Pre-stained marker.

SAM2 gene showed more than 17 fold higher enzyme activity as compared to control.

\section{Production of SAM in the bioreactor}

The clone GS115-SAM2 was cultivated in the bioreactor for production of SAM. The clone was initially grown on glycerol as the sole carbon source for $\sim 28 \mathrm{~h}$. Then feeding with methanol was continued for a further period of $90 \mathrm{~h}$. SDS-PAGE analysis of the recombinant $P$. pastoris revealed $\sim 42 \mathrm{kDa}$ SAM synthetase protein, from 12-90 $\mathrm{h}$ induction, with maximum expression of recombinant SAM synthetase from 48-60 h. Accumulation of SAM in the bioreactor also increased gradually from 12 to $72 \mathrm{~h}$ and there was no increase in the accumulation after $72 \mathrm{~h}$ (Figure $4 \mathrm{~b}$ ). At the end of cultivation of the recombinant $P$. pastoris, wet cell weight of $117 \mathrm{~g} / \mathrm{L}$ was achieved (Figure 4a). The recombinant $P$. pastoris cultured in the bioreactor, enriched with methionine could accumulate $2.4 \mathrm{~g} / \mathrm{l} \mathrm{SAM} \mathrm{(Figure} 4 \mathrm{a}$ ) or $0.021 \mathrm{~g} / \mathrm{g} \mathrm{WCW}$ or $0.186 \mathrm{~g} / \mathrm{g} \mathrm{DCW}$.

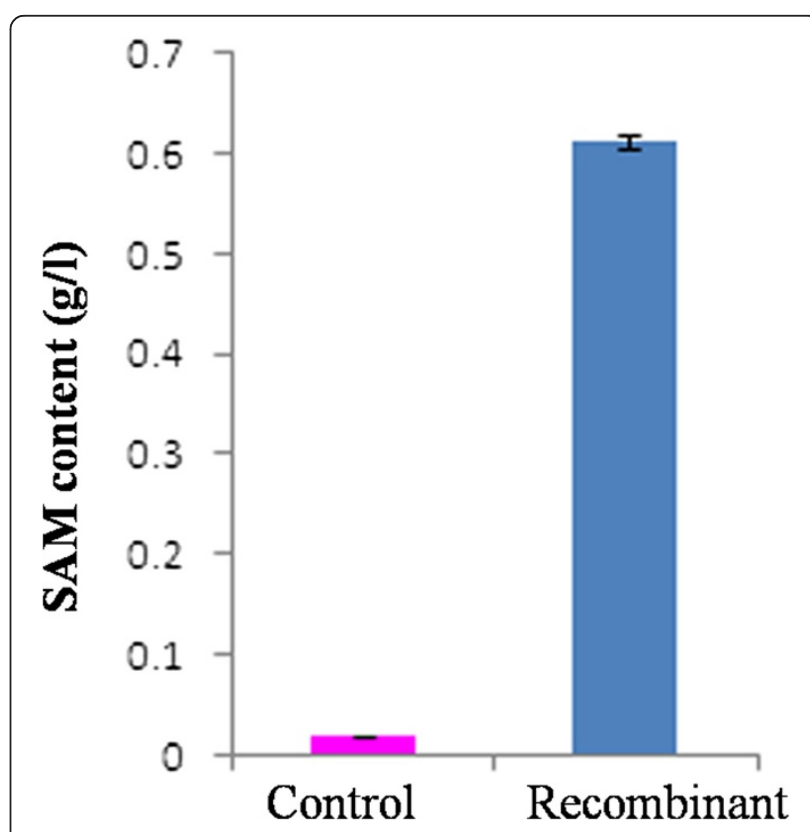

Figure 3 Recombinant $P$. pastoris GS115 expressing SAM2 gene when cultured in shake flask accumulated 33-fold higher SAM content as compared to Vector alone transformed strain of GS115. 

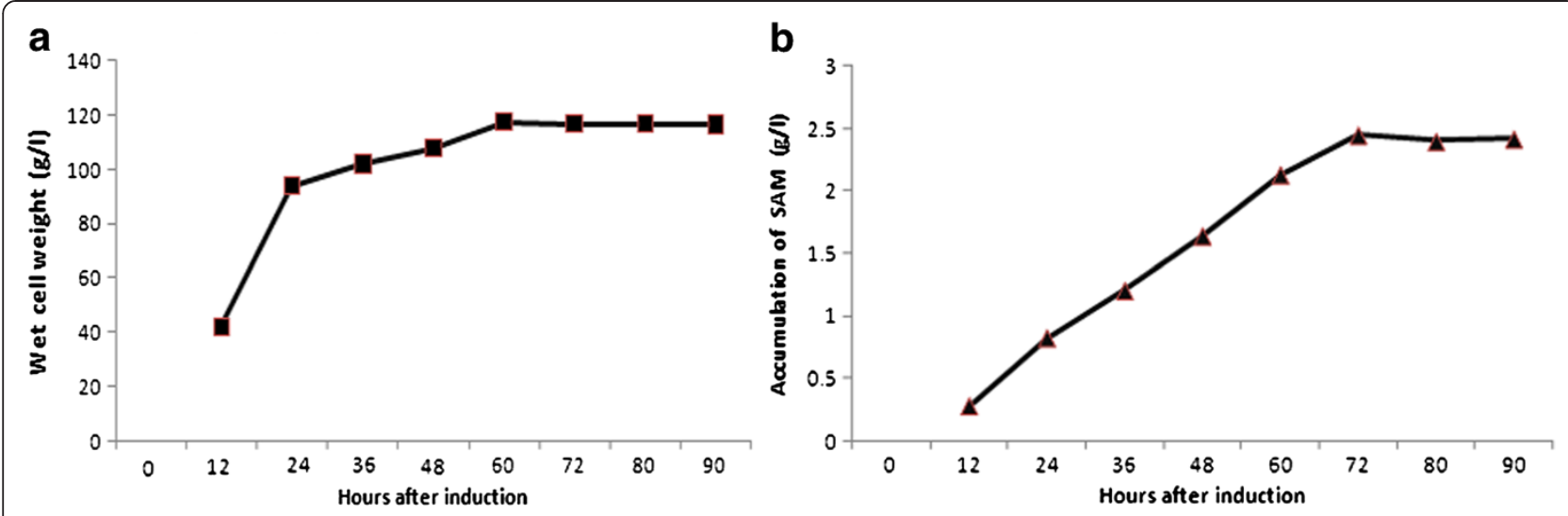

Figure 4 Gain in wet cell weight and accumulation of SAM in the recombinant $P$. pastoris GS115 cultured in bioreactor at different time points after induction with methanol. a Wet cell weight $\mathbf{b}$ SAM content.

LC-MS/MS analysis of the extract of recombinant $P$. pastoris LC/MS analysis of acid-extracted fermented cells exhibited distinct chromatographic peaks at retention times $\left(t_{R}\right)$ of 1.4, 1.5, 2.7, 4.2 and 5.8 minutes (Figure 5). The ESI mass spectrum of the chromatographic peak eluted at a $t_{R}$ of 2.7 minutes (Figure 6), and the spectrum showed $[\mathrm{M}]^{+}$ion at $m / z 399$ as the base peak. The spectrum also showed moderately abundant fragment ion peaks at $m / z 355$, 298, 136 and highly abundant ion peak at $m / z 250$. The collision induced dissociation (CID) tandem mass spectrometry (MS/MS) of $\mathrm{m} / z 399$ at $12 \mathrm{eV}$ disclosed characteristic signals at $m / z 298, m / z 250, m / z 136$, and $m / z 102$ (Figure 7).

\section{Discussion}

Biosynthesis of SAM is catalyzed in cytosol of cell by SAM synthetase using ATP and L-methionine as the substrates. SAM presents a unique feature in which all its constituents participate in diverse biochemical reactions (Fontecave et al. 2004). SAM is being used as a drug to treat liver diseases, depression, osteoarthritis, fibromyalgia, and Alzheimer's disease ( $\mathrm{Lu} \mathrm{2000).} \mathrm{In}$ view of therapeutic importance of SAM, cost effective production of biologically active $(S, S)$ form in large quantities is the need of the hour. as developed by the overexpression of $S$. cerevisiae SAM synthetase. The recombinant $P$. Various strains belonged to $S$. cerevisiae (Shiomi et al. 1990), Kluyveromyces lactis (Mincheva et al. 2002) and S. sake (Shiozaki et al. 1984) with high productivity of SAM have been isolated. However, low culture densities achieved in the minimal medium was not suitable for an industrial production of SAM. In the present investigation, an engineered $P$. pastoris was cultivated in shake flask and bioreactor. As compared to control the engineered strain showed enhanced accumulation of SAM. Further, the accumulated SAM was characterized at molecular level by LC-MS/MS analysis.

Recombinant plasmid pPIC3.5-SAM2 linearized with Sac I enzyme and electroporated into P. pastoris GS115, showed growth on histidine deficient medium, thus suggesting the transformed nature of colonies. Most of the $\mathrm{His}^{+}$clones $(\sim 83 \%)$ exhibited growth on medium containing antibiotic G418, indicating the stability of the transformants. All the $\mathrm{His}^{+}$clones resistant to G418, when subjected to PCR analysis using $A O X 1$ primers, gave a faint amplification product $(\sim 2.2 \mathrm{~Kb})$ corresponding to the native $A O X 1$ gene and a bright amplification product $(\sim 1.4 \mathrm{~Kb})$ comprising of SAM2

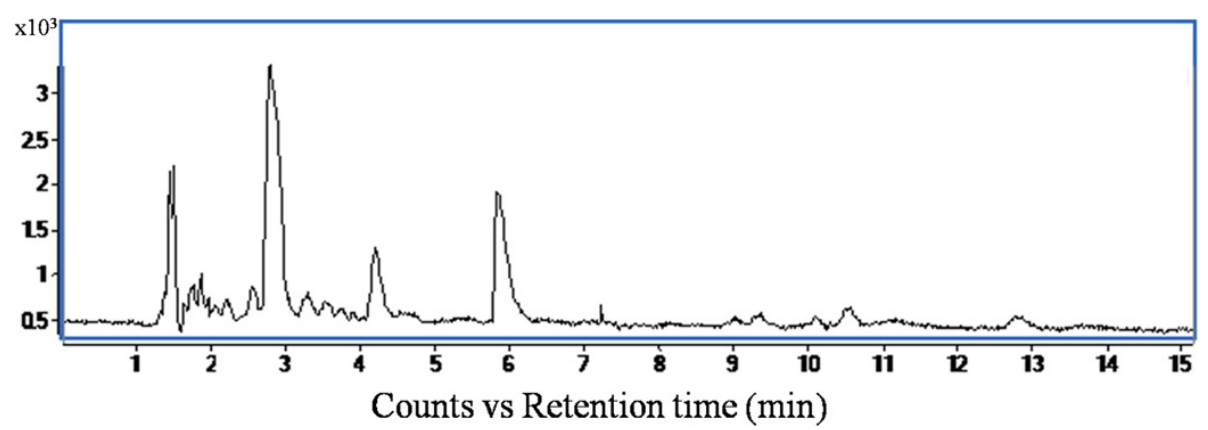

Figure 5 Total ion chromatogram using positive ESI-MS detection. 


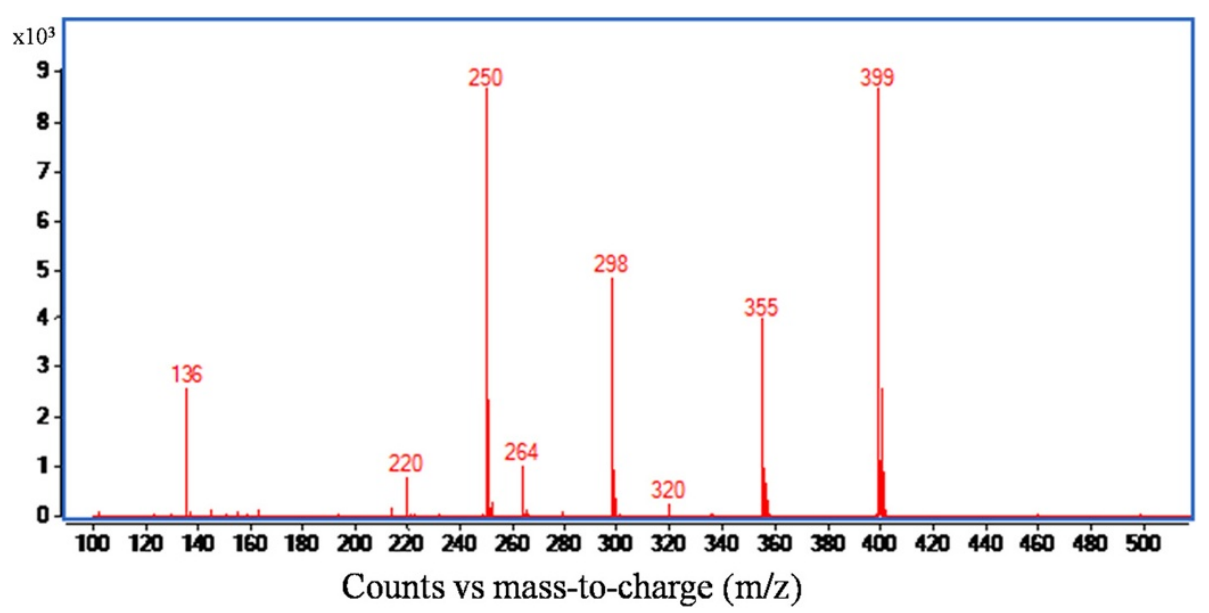

Figure $6 \mathrm{ESI}$ mass spectrum corresponds to $t_{R}$ at $2.7 \mathrm{~min}$.

gene, implying stable integration of recombinant plasmid, containing $S A M 2$, gene by homologous recombination at AOX1 in the genome of $P$. pastoris. All these clones exhibited $\mathrm{Mut}^{+}$phenotype. In an earlier study, it was found that amplification of both bands corresponding to the insert and $A O X 1$ gene was used as indication of $\mathrm{Mut}^{+}$phenotype, while $\mathrm{Mut}^{\mathrm{s}}$ was distinguished by the lack of amplification pertaining to native $A O X 1$ gene (Linder et al. 1996). Transformed clones exhibited varied levels of resistance to antibiotic G418. The variation observed for resistance to antibiotic is attributable to the variable copy number of Kanamycin resistance gene present in different transformants. Of the $250 \mathrm{His}^{+}$ clones only 15 of them exhibited growth on $2 \mathrm{mg} / \mathrm{ml} \mathrm{G418}$ containing medium, suggesting that these transformants might have acquired 4-7 copies of kanamycin resistance gene. Earlier studies, demonstrated a strong correlation between the integrated copies of the Kanamycin resistant gene into the $P$. pastoris genome and the degree of resistance to antibiotic G418. Further, it was established that $P$. pastoris transformants exhibiting tolerance to $0.25,0.5,1.0$ and $2.0 \mathrm{mg} / \mathrm{ml} \mathrm{G} 418$, showed the integration of 1 to 2, 3 to 4 and 4 to 7 copies, respectively, of kanamycin resistance gene (Scorer et al. 1994; He et al. 2006). Further, the level of resistance to antibiotic $(2 \mathrm{mg} / \mathrm{ml})$ revealed by different transformants amply testify the integration of 4-7 copies of SAM2 gene as these two genes are linked in the recombinant plasmid employed for genetic transformation.

In the shake flask experiment, SDS-PAGE analysis of engineered $P$. pastoris induced with methanol exhibited $\sim 42 \mathrm{kDa}$ protein band, while no such band was observed in the $P$. pastoris transformed with vector alone, confirming the expression of SAM2 gene in the heterologous host. As compared to control, engineered strain showed 17 fold higher enzyme activities than control

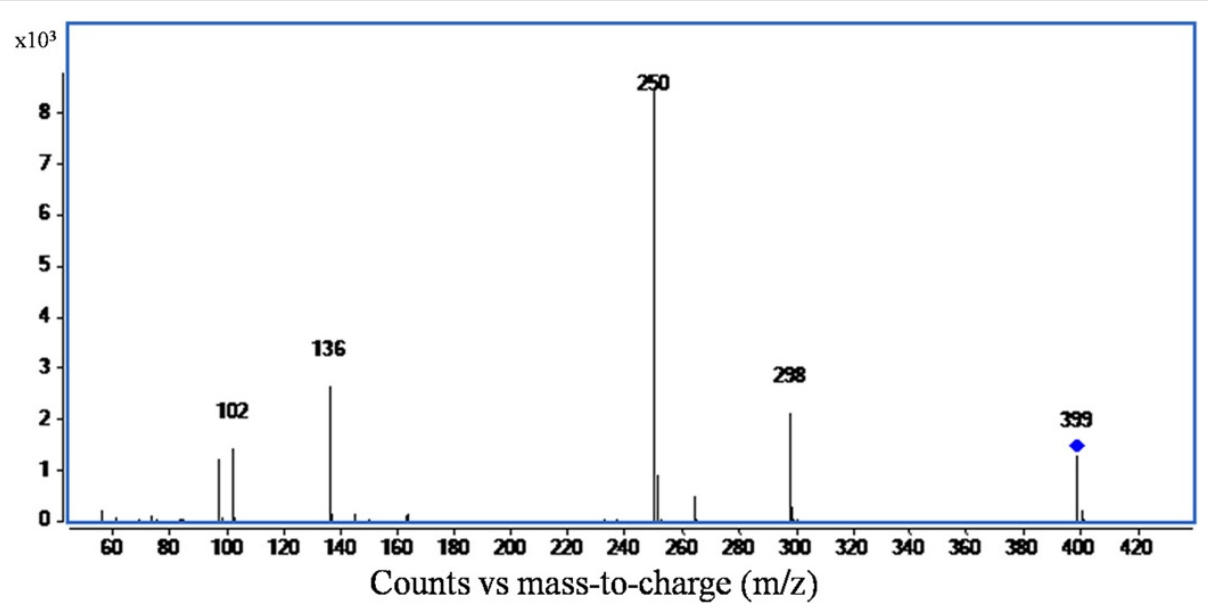

Figure 7 CID MS/MS spectrum of $m / z 399$ at $12 \mathrm{eV}$. 
strain, confirming the expression of SAM2 gene. Recombinant clone, cultured in L-methionine enriched medium, when subjected to methanol induction, accumulated 33-fold more SAM $(0.6 \mathrm{~g} / \mathrm{l})$ than the $P$. pastoris transformed with vector alone, in shake flasks culture, indicate the functional nature of heterologus SAM synthetase. The enhanced accumulation of SAM in the recombinant $P$. pastoris is attributable to the enriched substrate methionine and high-level expression of heterologus SAM synthetase insensitive to product inhibition, contributing to the increased SAM synthesis. In an earlier study, culturing of 9 different species of Saccharomyces in medium supplemented with L-methionine showed improved intracellular accumulation of SAM in these species. S. sake K-6 exhibited maximum accumulation of $12.6 \mu \mathrm{mol} \mathrm{SAM} \mathrm{(Shiozaki} \mathrm{et} \mathrm{al.} \mathrm{1989).} \mathrm{Enrichment}$ of culture medium with Precursor L-methionine increased the metabolic flux of SAM in various microorganisms (Shiozaki et al. 1984).

The engineered $P$. pastoris when cultivated in the bioreactor, promoted the harvest of $\sim 4.5$-fold increased WCW (117 g/l) in comparison with the shake flask cultures $(28 \mathrm{~g} / \mathrm{l})$. The significant increase observed in the production of WCW is ascribable to the optimum dissolved oxygen, nutrient balance and $\mathrm{pH}$ (5.8) maintained throughout the fermentation. Compared to shake flask cultures, cultivation of $P$. pastoris, expressing SAM2 gene, in the bioreactor produced 4-fold increases in SAM (2.4 g/l). Enhanced accumulation of SAM by the recombinant $P$. pastoris, when cultured on L-methionine enriched medium, in the bioreactor is mainly attributable to the increased WCW of P. pastoris. Accumulation of SAM in the bioreactor increased gradually from 12 to $72 \mathrm{~h}$ after methanol induction. SDS-PAGE analysis revealed that the expression of SAM2 was maximum after 48 to $60 \mathrm{~h}$ of induction with methanol. Inspite of the expression of SAM2 gene up to $90 \mathrm{~h}$, SAM accumulation tended to plateau after $72 \mathrm{~h}$, presumably because of the limited ATP available in the cells at stationary phase.

The acid extraction of fermented cells was analyzed and SAM was quantified by the HPLC. Molecular characterization of the SAM was carried out by MS/MS analysis and the ESI mass spectrum of the chromatographic peak, eluted at a $t_{R} 2.7$ minutes, disclosed $[\mathrm{M}]^{+}$ion at $\mathrm{m} / \mathrm{z}$ 399 as the base peak corresponding to the SAM. As SAM is positively charged because of the tertiary sulphur atom, hence, no $[\mathrm{M}+\mathrm{H}]^{+}$ion was observed. The collision induced dissociation, tandem mass spectrometry of $\mathrm{m} / \mathrm{z}$ 399 showed signals at $\mathrm{m} / z 298$ and at $\mathrm{m} / z 250$ indicating the loss of 2-amino 3-butenoic acid and methionine, respectively. The signals at $\mathrm{m} / z 136$ and at $\mathrm{m} / z 102$ represent protonated adenine and 2-amino 3-butenoic acid, respectively. These results confirm that the $\mathrm{m} / \mathrm{z}$ 399 peak eluted at $t_{R} 2.7$ minutes corresponds to SAM, and is in conformity with the established mass spectroscopic profiles of SAM (Struys et al. 2000).

In conclusion, S. cerevisiae SAM2 gene was successfully introduced in to the genome of $P$. pastoris under the control of $A O X 1$ promoter. In shake flask cultivation, the engineered $P$. pastoris could produce a 33-fold increase in SAM accumulation than the control P. pastoris transformed with the vector alone. In bioreactor, the engineered $P$. pastoris was grown to high cell densities and produced a four-fold increase in SAM accumulation than cultivation in the shake flask. The overall results amply demonstrate the overexpression of SAM2 gene in heterologus host $P$. pastoris lead to enhanced production of SAM when cultured in methionine enriched medium. The recombinant $P$. pastoris seems promising as potential source for industrial production of SAM.

Competing interests

The authors declare that they have no competing interests.

\section{Acknowledgements}

We express our grateful thanks to Department of Biotechnology, New Delhi for the facilities and support.

\section{Author details}

${ }^{1}$ Centre for Plant Molecular Biology, Osmania University, Hyderabad 500007 India. ${ }^{2}$ National Centre for Mass Spectroscopy, Indian Institute of Chemical Technology, Hyderabad 500 007, India.

Received: 29 May 2013 Accepted: 26 July 2013

Published: 27 July 2013

\section{References}

Bottiglieri T (2002) S-Adenosyl-L-methionine (SAMe): from the bench to the bedside-molecular basis of a pleiotrophic molecule. Am J Clin Nutr 76:1151S-1157S

Castillo C, Salazar V, Ariznavarreta C, Fossati M, Tresguerres JAF, Vara E (2005) Effect of S-adenosylmethionine on age-induced hepatocyte damage in old Wistar rats. Biogerontology 6:313-323

Cereghino JL, Cregg JM (2000) Heterologous protein expression in the methylotrophic yeast Pichia pastoris. FEMS Microbiol Rev 24:45-66

Chen H, Chu J, Zhang S, Zhuang Y, Qian J, Wang Y, Hu X (2007) Intracellular expression of Vitreoscilla hemoglobin improves S-adenosylmethionine production in a recombinant Pichia pastoris. Appl Microbiol Biotechnol 74:1205-1212

Cherest H, Surdin-Kerjan Y (1981) The two methionine adenosyl transferases in Saccharomyces cerevisiae: evidence for the existence of dimeric enzymes. Mol Gen Genet 182:65-69

Chiang PK, Cantoni GL (1977) Activation of methionine for transmethylation. Purification of the S-adenosylmethionine synthetase of bakers' yeast and its separation into two forms. J Biol Chem 252:4506-4513

Chiang PK, Gordon RK, Tal J, Zeng GC, Doctor BP, Pardhasaradhi K, McCann PP (1996) S-Adenosylmethionine and methylation. FASEB J 10:471-480

Chu J, Qian J, Zhuang Y, Zhang S, Li Y (2013) Progress in the research of S-adenosyl-L-methionine production. Appl Microbiol Biotechnol 97:41-49

Clare JJ, Rayment FB, Ballantine SP, Sreekrishna K, Romanos MA (1991) High-level expression of tetanus toxin fragment $C$ in Pichia pastoris strains containing multiple tandem integrations of the gene. Biotechnol 9:455-460

Cregg JM, Madden KR, Barringer KJ, Thill GP, Stillman CA (1989) Functional characterization of the two alcohol oxidase genes from the yeast Pichia pastoris. Mol Cell Biol 9:1316-1323

Cregg JM, Vedvick TS, Raschke WC (1993) Recent advances in the expression of foreign genes in Pichia pastoris. Biotechnol 11:905-910

Duff SJ, Murray WD (1988) Production and application of methylotrophic yeast Pichia pastoris. Biotechnol Bioeng 31:44-49 
Ellis SB, Brust PF, Koutz PJ, Waters AF, Harpold MM, Gingeras TR (1985) Isolation of alcohol oxidase and two other methanol regulatable genes from the yeast Pichia pastoris. Mol Cell Biol 5:1111-1121

Fontecave M, Atta M, Mulliez E (2004) S-adenosylmethionine: nothing goes to waste. Tren Biochem Sci 29:243-249

Garg N, Bieler N, Kenzom T, Chhabra M, Ansorge-Schumacher M, Mishra S (2012) Cloning, sequence analysis, expression of Cyathus bulleri laccase in Pichia pastoris and characterization of recombinant laccase. BMC Biotechnol 12:75

Grillo MA, Colombatto S (2007) S-adenosylmethionine and radical-based catalysis. Amino Acid 32:197-202

Guarna MM, Lesnicki GJ, Tam BM, Robinson J, Radziminski CZ, Hasenwinkle D, Boraston A, Jervis E, MacGillivray RT, Turner RF, Kilburn DG (1997) On-line monitoring and control of methanol concentration in shake-flask cultures of Pichia pastoris. Biotechnol Bioeng 56:279-286

Harmand MF, Vilamitjana J, Maloche E, Duphil R, Ducassou D (1987) Effects of S-adenosylmethionine on human articular chondrocyte differentiation - An in vitro study. Am J Med 83:48-54

He J, Deng J, Zheng Y, Gu J (2006) A synergistic effect on the production of S-adenosyl-L-methionine in Pichia pastoris by knocking in of S-adenosyl-Lmethionine synthase and knocking out of cystathionine-beta synthase. J Biotechnol 126:519-527

Hu H, Qian J, Chu J, Wang Y, Zhuang Y, Zhang S (2009) Optimization of L: -methionine feeding strategy for improving S-adenosyl-L: -methionine production by methionine adenosyltransferase overexpressed Pichia pastoris. Appl Microbiol Biotechnol 83:1105-1114

Kamarthapu V, Rao KV, Reddy VD, Srinivas PNBS (2008) Structural and kinetic properties of Bacillus Subtilis S-adenosylmethionine synthetase expressed in Escherichia coli. Biochimia et Biophysica Acta 1784:1949-1958

Lee JH, Lee SG, Do H, Park JC, Kim E, Choe YH, Han SJ, Kim HJ (2013) Optimization of the pilot-scale production of an ice-binding protein by fed-batch culture of Pichia pastoris. Appl Microbiol Biotechnol 97:3383-3393

Li DY, Yu J, Tian L, Ji XS, Yuan ZY (2002) Production of SAM by recombinant Pichia pastoris. Chin J Biotechnol 18:295-299

Lin JP, Tian J, You JF, Jin ZH, Xu ZN, Cen PL (2004) An effective strategy for the co-production of S-adenosyl-I-methionine and glutathione by fed-batch fermentation. Biochem Eng J 21:19-25

Linder S, Schliwa M, Kube-Granderath E (1996) Direct PCR screening of Pichia pastoris clones. Bio Techn 20:980-982

Lu SC (2000) S-Adenosylmethionine. Int J Biochem Cell Biol 32:391-395

Lu SC, Mato JM (2008) S-Adenosylmethionine in cell growth, apoptosis and liver cancer. J Gastroenterol Hepatol 23:S73-S77

Macauley-Patrick S, Fazenda ML, McNeil B, Harvey LM (2005) Heterologous protein production using the Pichia pastoris expression system. Yeast 22:249-270

Mincheva K, Kamburova V, Balutzov V (2002) Production of S-adenosyl- L-methionine by a mutant strain of Kluyveromyces lactis. Biotechnol Lett 24:985-988

Mischoulon D, Alpert JE, Arning E, Bottiglieri T, Fava M, Papakostas Gl (2012) Bioavailability of S-adenosyl methionine and impact on response in a randomized, double-blind, placebo-controlled trial in major depressive disorder. J Clin Psychiatr 73:843-848

Papakostas Gl, Alpert JE, Fava M (2003) S-adenosyl-methionine in depression: a comprehensive review of the literature. Curr Psychiatr Rep 5:460-466

Papakostas Gl, Cassiello CF, lovieno N (2012) Folates and S-adenosylmethionine for major depressive disorder. Can J Psychiatr 57:406-413

Ringdahl E, Pandit S (2011) Treatment of knee osteoarthritis. Am Fam Phys 83:1287-1292

Roje S (2006) S-Adenosyl-L-methionine: beyond the universal methyl group donor. Phytochem 67:1686-1698

Sambrook J, Russel DW (2001) Molecular cloning a laboratory manual. Cold Spring Harbor laboratory press, New York, Vol.1, 2 and 3

Scorer CA, Clare JJ, McCombie WR, Romanos MA, Sreekrishna K (1994) Rapid selection using G418 of high copy number transformants of Pichia pastoris for high-level foreign gene expression. Biotechnol 12:181-184

Shiomi N, Fukuda H, Fukuda Y, Murata K, Kimura A (1990) Production of S-adenosyl-L-methionine by Saccharomyces cerevisiae cells carrying a gene for ethionine resistance. Biotechnol Bioeng 35:1120-1124

Shiozaki S, Shimizu S, Yamada H (1984) Unusual intracellular accumulation of S-adenosyl-L-methionine by microorganisms. Agr Biol Chem 48:2293-2300

Shiozaki S, Shimizu S, Yamada H (1989) S-Adenosyl-L-methionine Production by Saccharomyces sake: Optimization of the Culture Conditions for the Production of Cells with a High S-Adenosyl-L-methionine Content. Agr Biol Chem 53:3269-3274
Shobayashi M, Mukai N, Iwashita K, Hiraga Y, lefuji H (2006) A new method for isolation of S-adenosylmethionine (SAM)-accumulating yeast. Appl Microbiol Biotechnol 69:704-710

Sreekrishna K, Potenz RH, Cruze JA, McCombie WR, Parker KA, Nelles L, Mazzaferro PK, Holden KA, Harrison RG, Wood PJ (1988) High level expression of heterologous proteins in methylotrophic yeast Pichia pastoris. J Basic Microbiol 28:265-278

Struys EA, Jansen EE, de Meer K, Jakobs C (2000) Determination of $\mathrm{S}$-adenosylmethionine and S-adenosylhomocysteine in plasma and cerebrospinal fluid by stable-isotope dilution tandem mass spectrometry. Clin Chem 46:1650-1656

Thomas D, Rothstein R, Rosenberg N, Surdin-Kerjan Y (1988) SAM2 encodes the second methionine S-adenosyl transferase in Saccharomyces cerevisiae: physiology and regulation of both enzymes. Mol Cell Biol 8:5132-5139

Tschopp JF, Brust PF, Cregg JM, Stillman CA, Gingeras TR (1987) Expression of the lacZ gene from two methanol-regulated promoters in Pichia pastoris. Nucleic Acids Res 15:3859-3876

Yu P, Shen X (2012) Enhancing the production of S-adenosyl-L-methionine in Pichia pastoris GS115 by metabolic engineering. AMB Express 2:57

Yu ZL, Wu XJ, Li DY, Yang S, Zhou Z, Cai J, Yuan ZY (2003) Enhancement of the production of SAM by overexpression of SAM synthetase in Pichia pastoris. Acta Biochim Biophys Sin 35:127-132

Zhang J, Wang X, Zheng Y, Fang G, Wei D (2008a) Enhancing yield of S-adenosylmethionine in Pichia pastoris by controlling $\mathrm{NH} 4+$ concentration. J Biosci Bioeng 31:63-67

Zhang JG, Wang XD, Zhang JN, Wei DZ (2008b) Oxygen vectors used for S-adenosylmethionine production in recombinant Pichia pastoris with sorbitol as supplemental carbon source. J Biosci Bioeng 105:335-340

doi:10.1186/2191-0855-3-40

Cite this article as: Kamarthapu et al:: Engineered Pichia pastoris for enhanced production of S-adenosylmethionine. AMB Express 2013 3:40.

\section{Submit your manuscript to a SpringerOpen ${ }^{\circ}$ journal and benefit from:}

- Convenient online submission

$\checkmark$ Rigorous peer review

- Immediate publication on acceptance

- Open access: articles freely available online

- High visibility within the field

- Retaining the copyright to your article

Submit your next manuscript at springeropen.com 